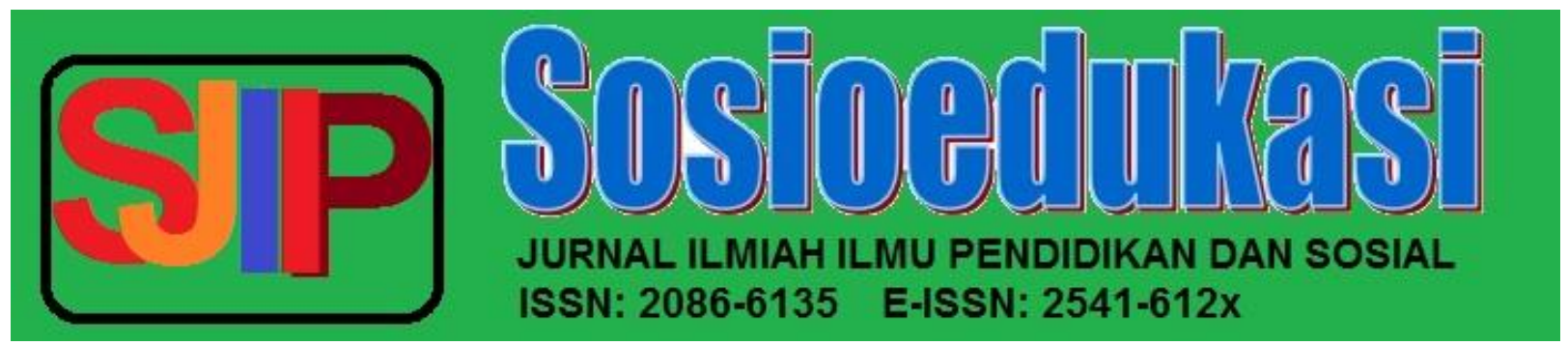

November Vol.9 No. 2 Tahun 2020 https://ejournal.unibabwi.ac.id/index.php/sosioedukasi/index

\title{
APPLICATION OF COOPERATIVE LEARNING METHODS WITH THINK PAIR AND SHARE MODEL ON-LINE TYPE TO IMPROVE STUDENT COOPERATION
}

\author{
Moh. Sabab Nashrulloh \\ SMA Assa'adah, Bungah-Gresik \\ nashrulloh.nash28@gmail.com
}

\begin{abstract}
ARTICLE HISTORY
ABSTRACT

Received : $2310-2020$

The Think Pair and Shairecooperative (TPS)learning method is a learning method in the form of group discussions which is commonly applied in face-to-face learning. It is new if the TPS model of cooperative learning method is applied in a network that remembers the pandemic situation and in the new learning year at school. Where the cooperative method becomes a discussion method that makes the cooperation of students more active and can socialize among new students in particular. This condition is necessary and good for students to increase cooperation and the socialization process between school friends. This study uses observation methods in data collection and uses cycle description methods in data analysis. This research generates new knowledge that cooperative research methods can be carried out in networks and using the Think Pair and Shaire model can positively increase cooperation between students and create a space for socialization among new students in particular.

Cooperative Learning

Methods;

Think Pair and Shair Models;

Collaboration
\end{abstract}

This is an open access article under the CC-BY-SA license.

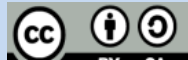

INTRODUCTIONS

The current pandemic that has hit the world and is no exception in Indonesia which is caused by the covid 19 virus requires large-scale restrictions on various aspects of life. Not only on the social, economic, religious aspects, even the educational aspects cannot be separated from the impact. The consequence is that in the educational process it is necessary to carry out learning in a network (online) or it can be known as virtual learning. It is indeed a relatively new learning act that can even be said to be a cultural shock in the world of education and the teaching and learning process.

When viewed first the teaching and learning process is only in the classroom then the teacher and students face to face directly. However, this cannot be done online as it is today. All schools are encouraged to make learning through the network(Online).This is as said by the Expert 


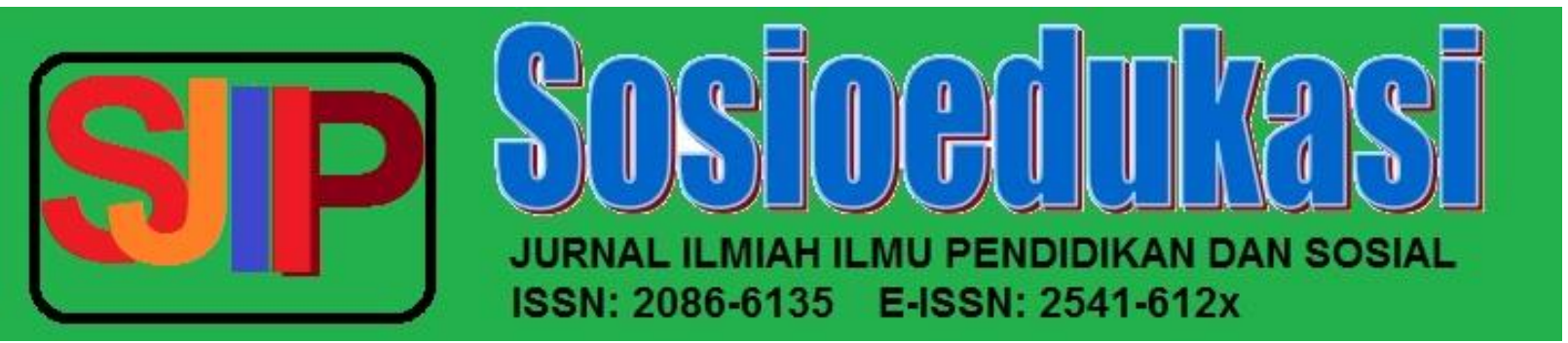

November Vol.9 No. 2 Tahun 2020 https://ejournal.unibabwi.ac.id/index.php/sosioedukasi/index

Staff of the Minister of Education and Culture in the Field Regulation, Chatarina Muliana Girsang conveyed this Circular Letter Number 15 for Strengthen the Circular of the Minister of Education and Culture Number 4 of 2020 concerning Implementation Coronavirus Disease (Covid-19) Emergency Education. Say that (Depdikbud. 2020) "Currently, learning services are still following the Minister of Education and Culture SE number 4 of 2020 which is strengthened by SE Secretary General number 15 of 2020 concerning Guidelines for the Implementation of BDR during the Covid-19 emergency, "and" The current choices are the main thing is to break the chain of Covid19 with the maximum existing conditions perhaps, while still working to meet education services. In principle physical and mental health and safety of students, educators, school principals, and all citizens of the education unit is to be a major consideration in the pime Frame learn from home, "

Online Learning and Working from Home to Prevent Spread COVID-19 to ensure that control, vigilance, and handling of the

spread of Covid-19 in his work unit have been implemented properly in accordance with Circular of the Minister of Education and Culture Number 2 Year $2 \mathrm{O} 2 \mathrm{O}$ and Number 3 Year $2 \mathrm{O} 2 \mathrm{O}$ concerning the Prevention and Management of CoronaVirus Disease (Covid-19), March 9, 2020 (Jogloabang. 2020). There are regulations that state learning from home through online so that teachers should too adjust. teachers are also required to do maximum learning and not lost to direct face-to-face learning in the classroom. teachers are also required to be creative and think at a higher level in using the media learning so that learning runs optimally and well. learning good also cannot be separated from the learning methods used.

The cooperative learning method is one of the learning methods supports contextual learning. Cooperative learning systems can defined as a structured group work / study system. Included in in this structure are five main elements (Jogloabang. 2020), namely each other positive dependence, individual responsibility, personal interaction, work skills the same, and group processes.

Doing learning which is usually done face-to-face with online learning is of course different. Demanding online learning the use of media (LMS) as a class in the learning process. But you have to we do in maximizing the learning process. because with interactions fellow students can also form character and socialization in it. cooperative learning methods cannot be ignored in the learning process either face-to-face or online learning.

Seeing the type of cooperative learning method is very effective and is usually done in the face-to-face learning process. It is interesting, different and relatively new when this cooperative 


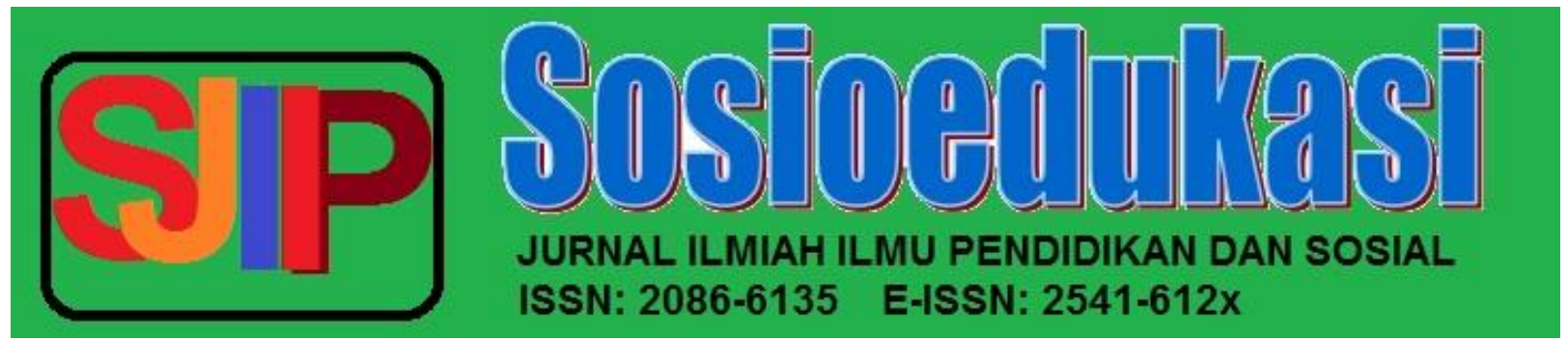

November Vol.9 No. 2 Tahun 2020 https://ejournal.unibabwi.ac.id/index.php/sosioedukasi/index

learning method is carried out in a network using platforms certain. It is not easy if the cooperative learning method is done online but it is not impossible if it is done in the learning process online.

Think Pair Share (TPS) or thinking in pairs sharing is a type of cooperative learning designed to influence student interaction patterns. This Think Pair Share strategy developed from research on cooperative learning and waiting time. First developed by Frang Lyman and colleagues at the University of Maryland, as quoted by Arends, states that Think Pair Share is an effective way to vary the atmosphere of classroom discussion patterns. Assuming that all recitation or discussion requires arrangements to control the class as a whole, and the procedures used in Think Pair Share can give students time to think, to respond to and help each other. The teacher estimates that only completing the brief presentation or students reading the assignment, or situations that become question marks. Now the teacher wants students to consider more of what has been explained and experienced. The teacher chooses to use Think Pair Share to compare the question and answer of the whole group (Trianto Ibnu Badar Al-Tabany. 2014).

The benefits of Think Pair Share include: 1) enabling students to work alone and collaborating with others, 2) optimizing student participation and 3) providing opportunities for students to show their participation to others. The abilities that are generally needed in this strategy are sharing information, asking questions, summarizing other people's ideas, and analyzing (Miftahul Huda. 2013).

Online learning is learning that uses internet networks with accessibility, connectivity, flexibility, and the ability to generate various types of learning interactions. Research conducted by Zhang et al., (2004) shows that the use of the internet and multimedia technology is able to change the way of conveying knowledge and can be an alternative to learning carried out in traditional classrooms. Online learning is learning that is able to bring together students and lecturers to carry out learning interactions with the help of the internet (Kuntarto, E .. 2017). At the implementation level, online learning requires the support of mobile devices such as smartphones or Android phones, laptops, computers, tablets, and iPhones which can be used to access information anytime and anywhere (Gikas, J., \& Grant, MM. 2013). Universities during the WFH period need to carry out strengthening of online learning (Darmalaksana, W.: 2020). Online learning has become a demand for education since the last few years (He, W., Xu, G., \& Kruck, S.:2014). Online learning is needed in learning in the era of the industrial revolution 4.0 (Pangondian, RA, Santosa, PI, \& Nugroho, E. (2019). 


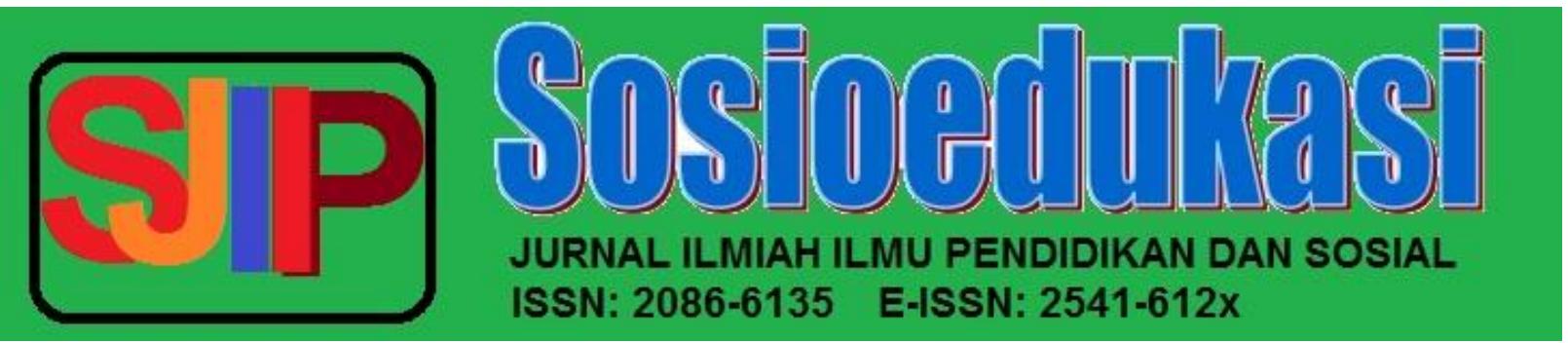

November Vol.9 No. 2 Tahun 2020 https://ejournal.unibabwi.ac.id/index.php/sosioedukasi/index

Basically not only cooperative learning methods are new. But online learning is also basically as well. It is relatively new and it is possible that teachers and students are still in the adaptation stage. So that it becomes a challenge when applying cooperative learning methods. The actual learning must be implemented and if it is applied it has good benefits for students and becomes a learning form that can be done through the network.

\section{MATERIALS AND METHODS RESEARCH LOCATION}

This study used the observation method in data collection and used the cycle description method in data analysis. The subjects of this study were 33 students of class X-IPS 2. The total number of participants was female. the subject of this action research on the grounds that some students in this class have high learning motivation so that with the application of online learning types they still have high learning motivation compared to other classes. The researcher is a sociology teacher at Assa'dah High School, Bungah - Gresik.

This research is divided into 3 cycles in data collection. Where from each stage consists of: the first stage of planning. At the planning stage the researcher makes a RPP design, prepares paper media containing topics or material to be discussed and markers needed in the application of learning, prepares instruments to analyze data about the learning process taking place and the results of the action, namely: Worksheets in the form of questions for interviews, teacher observation sheets, students and assessment instruments.

Second: the observation stage. At this observation stage, the researcher made observations about all the learning implementation processes that took place to make learning improvements with the cooperative learning method think pair and share (TPS) type in the network in class X-IPS 2 SMA Assa'adah Bungah Gresik.

The third stage is the reflection stage: At this stage the researcher analyzes the results of observations in cycle I. The researcher conducts an evaluation, which is in order to identify deficiencies in cycle I. The analysis is carried out to measure the weaknesses and strengths that exist during the learning process. If the research results are not as expected, the next cycle will be carried out. The strengths that exist in the first cycle are maintained and improve the existing deficiencies, so that the results of this reflection analysis are a determinant of the success of the learning process using the think pair and share (TPS) type in network cooperative learning method on the material understanding of Sociology and background. the birth of sociology. 


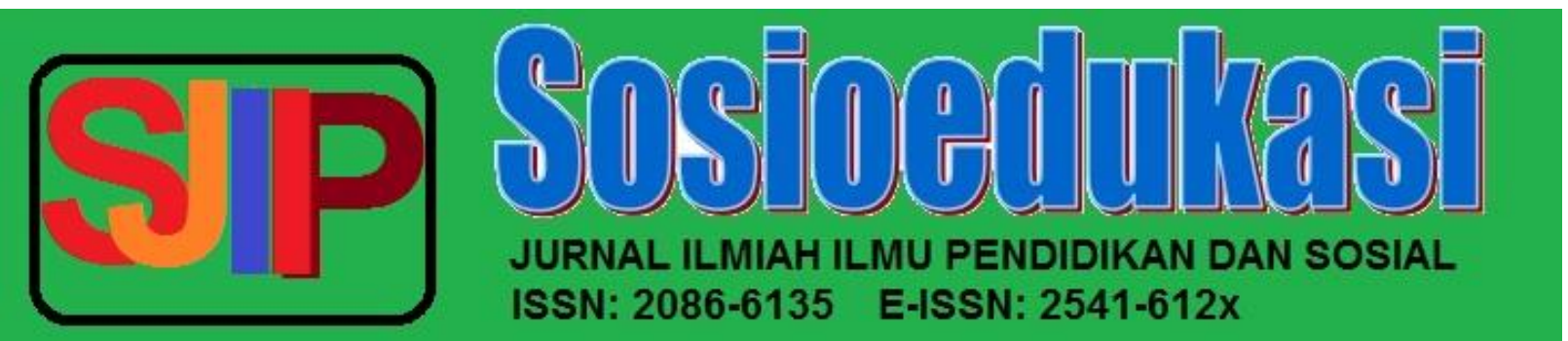

November Vol.9 No. 2 Tahun 2020 https://ejournal.unibabwi.ac.id/index.php/sosioedukasi/index

\section{RESULTS AND DISCUSSIONS}

Given the conditions of the Covid 19 pandemic which require online learning. So face to face, of course, has almost never been done before. the previous learning process was carried out by virtual or virtual face-to-face. Therefore, with the capital of personal experience and the results of observations from the information of the teachers who taught in class X IPS decided that class X IPS 2 was the class that was used as a research class. Observations were made during the class starting from the beginning of the new teaching until the research was about to begin.

The benefits of this research are very important because by doing this research it is hoped that later it can create a collaboration and socialization between new students. It is hoped that closeness and getting to know each other will become a new breakthrough in creating social and emotional conditions in the network. Indeed, this has not been done so far and has only been done so far face-to-face. Introductions between students are carried out in real classes with real communication and working on joint assignments. Character building between students is considered very important in creating good character building and collaboration in the classroom even though it is done in a network or virtual.

Giving an assignment with a group discussion requires students to cooperate and communicate with one another in formulating answers or common goals. This is expected to create a socialization environment and opportunities to interact and get to know each other between students and other students, who in fact they are new students in the school environment who need social and emotional introductions and bonds between one another and that is very important for the world. their social education.

On average, most of the new classes and with this networked learning condition are usually done individually without involving cooperation and cohesiveness between groups. This is rarely and almost never done because it is estimated that the complexity and many obstacles will occur in the learning process and assignment collection. This is so that students can mostly do not know each other and even have never communicated and introduced each other.

By using the discussion learning method (cooperative), it is expected that there will be cooperation and socialization among students. This existence is able to create a good new social environment and a strong emotional bond between students whose benefits are very much in the future, one of which

makes it smoother and helps each other in the learning process that will be carried out in the future. 


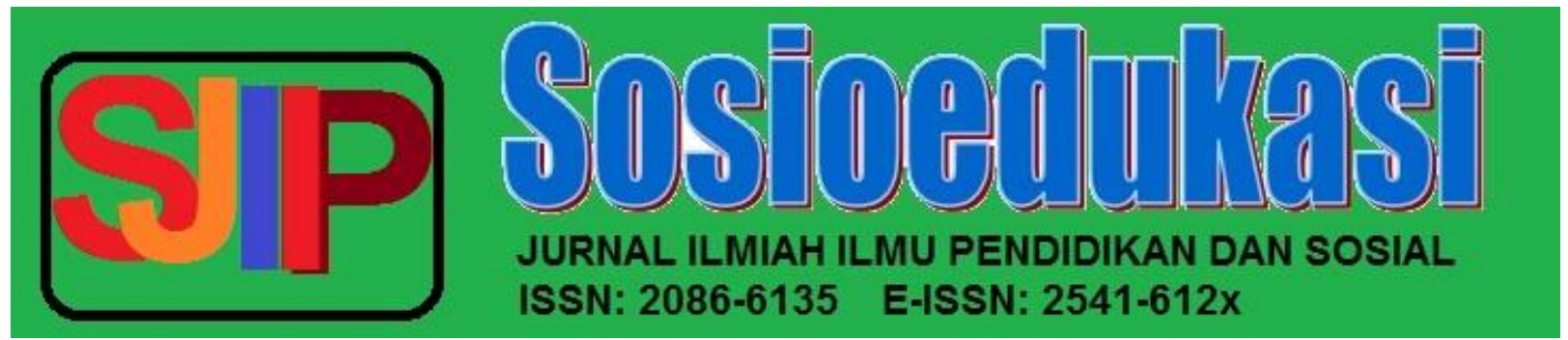

November Vol.9 No. 2 Tahun 2020 https://ejournal.unibabwi.ac.id/index.php/sosioedukasi/index

So this research emphasizes on increasing cooperation in cooperative learning models. It is hoped that later new students can work together well and become a forum for socialization and communication between peers in learning at school. Because it also has good benefits in character building and peer socialization. If the new students have formed a socialization environment and know each other well, it is hoped that the class will run well and be well coordinated as a new class in the network.

First cycle. At this stage the results of observations from the actions that the researcher has taken as a teacher, reflect. The purpose of reflection itself is to determine the application of the cooperative learning method of the Think Pair and Share model is successful in increasing the learning cooperation of class X IPS 2 students in sociology lessons. The results of data analysis carried out at this stage will be used as a reference for planning actions in the next cycle. Based on the results of observations and interpretation of actions in cycle I, the researcher can provide the following analysis: In the learning process at first it was going well. the learning process is only choked up in the signal problem that makes children sometimes come in and out and do not follow the learning material properly. so that students also do not understand and follow the learning process from start to finish well. But for the teachers themselves, learning has gone through a process or learning stage in accordance with the previously planned planning. this will be a correction later in the coordination of students at the next stage. But when faced with a network problem it will be difficult and difficult to repair, but uru will work hard in the process of further learning.

Based on the variable that becomes the problem, namely about cooperation. At this early cycle. In terms of learning it has been going well. Likewise the discussion using the Think Pair and Shair model students can discuss well and the discussion process goes accordingly. because indeed in the discussion model this time students have provisions in giving opinions by thinking privately first so that students are confident to issue an opinion that has been done before.

If you see the deficiencies in this learning is more classical and systemic. Because indeed students have never had to conduct previous learning discussions online so that students have a little difficulty and are still stammering in carrying out the discussion stages. However, the learning so far has gone well and went through the process according to previous planning.

In the second cycle, at this stage the results of observations of the actions that the researcher has taken as a teacher, reflect. The purpose of reflection itself is to determine the application of cooperative learning methods Group Resume (GR) model is successful in increasing the learning 


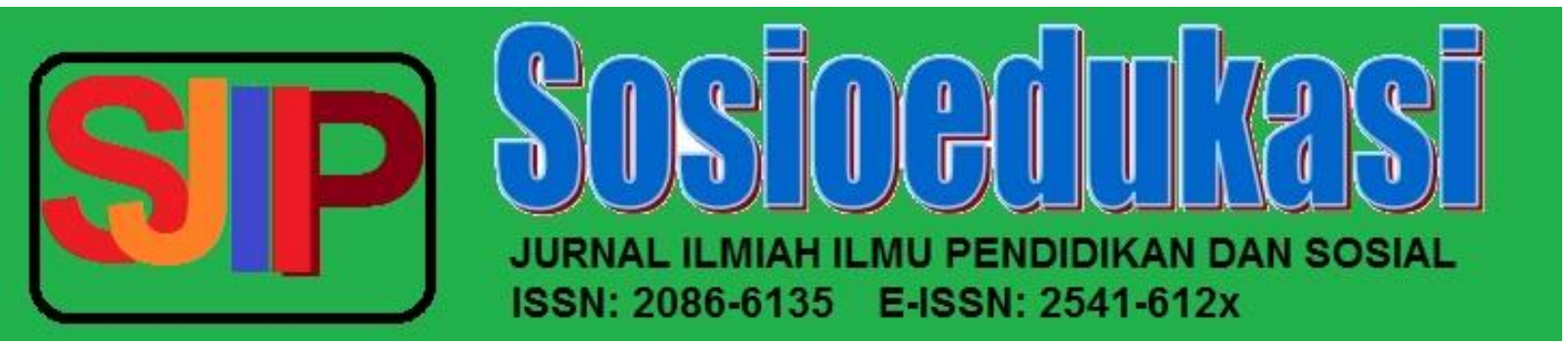

November Vol.9 No. 2 Tahun 2020 https://ejournal.unibabwi.ac.id/index.php/sosioedukasi/index

cooperation of class X IPS 2 students in sociology lessons. The results of data analysis carried out at this stage will be used as a result of analysis and consideration in concluding the analysis. Based on the results of observation and interpretation of actions in cycle II, the researcher can provide the following analysis: In the second cycle, students also did

well in the introduction. Students also follow the learning process in accordance with what they want at first and it is hoped that the discussion process will further enhance good cooperation. the learning process is more improved than the learning process carried out earlier in the first cycle.

The discussion process at this meeting did not seem to be going well. feels like using the Group resume model, this time the students were seen having difficulty in conducting and starting the discussion process by directly gathering students in the discussion group. Students are a little difficult and awkward to express their opinion the first time. Most students seem to hang answers on other friends. It is as if the answer has been answered, it is their obligation to have less opinion. It is as if students put forward the results of the discussion process carried out at each stage of the scores carried out.

As a result, students were able to do LKPD well and all were answered, but in the discussion process there was less cooperation and the intensity of coordination of answers also decreased. So it can be said that the discussion process this time by looking at the cooperation carried out has decreased compared to the cycle that was done in the previous first cycle.

In the third cycle: in this third cycle the researcher returns to the Think Pair and Shair research model as in the first cycle. Because researchers using types in the network feel that the model is best used to increase cooperation between students.

The difference is that in the first cycle students are not burdened with the products of the discussion. However, in cycle three the teacher gave assignments using discussion products which would later be presented one by one at a web meeting. So that there is more burden in discussion than in the first cycle.

With the product that is produced and displayed in the discussion process, students will collaborate and discuss more intensely. So it can be said that there is an increase in more cooperation among students with the Think Pair and Shair model and can be used in networks as a model to increase cooperation.

\section{CONCLUSION}




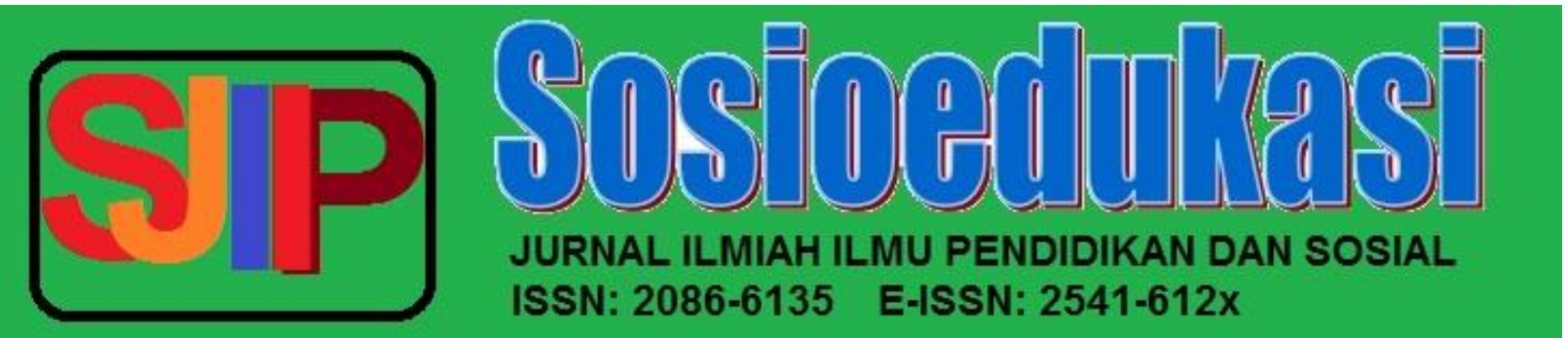

November Vol.9 No. 2 Tahun 2020 https://ejournal.unibabwi.ac.id/index.php/sosioedukasi/index

1. The cooperative method can not only be used in face-to-face learning, but can be used with types in the network.

2. Think Pair and Shair model can increase cooperation between students in the learning process.

3. With the Think Pair and Shair model, producing products will further enhance cooperation.

4. The discussion process becomes a medium of interaction and communication between new students in shaping the social environment at school.

\section{REFERENCES}

Darmalaksana, W. (2020). WhatsApp Kuliah Mobile . Fakultas Ushuluddin UIN Sunan Gunung Djati Bandung.

Gikas, J., \& Grant, M. M. (2013). Mobile computing devices in higher education: Student perspectives on learning with cellphones, smartphones \& social media. Internet and Higher Education. https://doi.org/10.1016/jjheduc.2013.06.002.

He, W., Xu, G., \& Kruck, S. (2014). Online IS Education for the 21st Century . Journal of Information Systems Education.

Jogloabang. 2020. Pembelajaran daring dan bekerja dari rumah untuk pencegahan penyebaran covid19. (Online). https://www.jogloabang.com/pendidikan/pembelajaran-daring-bekerja-rumahpencegahan-penyebaran-covid-19 Diakses: 12/10/2020.

Johnson dan Johnson. 1993. Metode Cooperative Learning Type Jigsaw. Jakarta: Erlangga.

Kuntarto, E. (2017). Keefektifan Model Pembelajaran Daring dalam Perkuliahan Bahasa Indonesia di Perguruan Tinggi. Indonesian Language Education and Literature, 3(1), 99-110. 10.24235/ileal.v3i1.1820.

Miftahul Huda, Model-model Pengajaran dan Pembelajaran, (Yogyakarta: Pustaka Pelajar, 2013).

Pangondian, R. A., Santosa, P. I., \& Nugroho, E. (2019). Faktor-Faktor Yang Mempengaruhi Kesuksesan Pembelajaran Daring Dalam Revolusi Industri 4.0. In Seminar Nasional Teknologi Komputer \& Sains (SAINTEKS) (Vol. 1, No. 1).

Pengelola web kemendikbud. 2020. (Online). https://www.kemdikbud.go.id/main/blog/2020/05/ kemendikbud-terbitkan-pedoman-penyelenggaraan-belajar-dari-rumah. diakses: 12/10/2020.

Trianto Ibnu Badar Al-Tabany, Mendesain Model Pembelajaran, (Jakarta: Prenadamedia Group, 2014) 


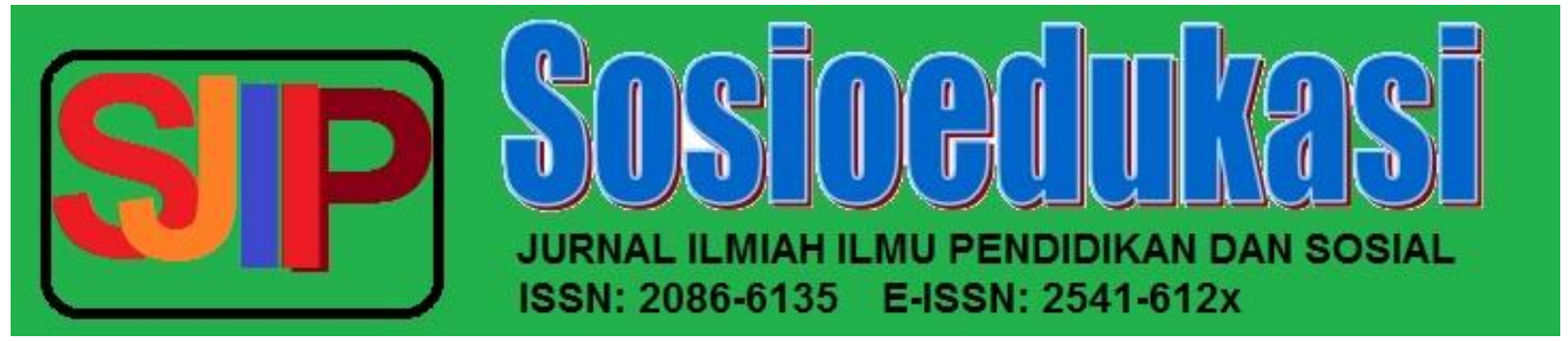

November Vol.9 No. 2 Tahun 2020

https://ejournal.unibabwi.ac.id/index.php/sosioedukasi/index

Zhang, D., Zhao, J. L., Zhou, L., \& Nunamaker, J. F. (2004). Can e-learning replace classroom learning? Communications of the ACM. https://doi.org/10.1145/986213.986216. 